\title{
STUDI KARAKTERISTIK REAKTOR GASIFIKASI TYPE DOWNDRAFT SERBUK KAYU DENGAN VARIASI EQUIVALENSI RATIO
}

\author{
Suliono $^{1)}$, Bambang Sudarmanta ${ }^{2)}$, Felix Dionisius ${ }^{3)}$, Imam Maolana ${ }^{4)}$ \\ 1,3,4 Jurusan Teknik Mesin Politeknik Negeri Indramayu, Jl. Lohbener Lama No. 08 Indramayu 45252 Fax/Telp. \\ (0234)5746464, \\ ${ }^{2}$ Jurusan Teknik Mesin FTI-ITS, Kampus ITS Keputih-sukolilo Surabaya, 6011. Telp: (031) 5946230. Fax: (031) \\ 5922941 \\ E-mail : sulionolee@gmail.com ${ }^{1}$, sudarmanta@me.its.ac.id ${ }^{2}$, dionisiusfelix@gmail.com ${ }^{3}$, \\ imam_malau@yahoo.com ${ }^{4}$
}

\begin{abstract}
Abstrak
Menipisnya cadangan bahan bakar fosil dan gas alam membuat manusia berfikir ulang untuk mencari pengganti energi aletrnatif. Biomassa merupakan energi alternatif yang masih melimpah dan belum termanfaatkan secara maksimal. Gasifikasi merupakan salah satu alternatif dalam pembuatan gas yaitu mengubah dari bahan bakar padat (serbuk kayu) menjadi gas yang mudah terbakar secara termokimia. Penelitian menggunakan gasifikasi tipe downdraft dengan bahan serbuk kayu secara eksperimental. Pelaksanaan penelitan dilakukan diworkshop kampus Polindra, menggunakan sistem batch, artinya 1 kali pemasukan biomassa pada tungku dari awal sampai biomassa habis sebesar $5 \mathrm{~kg}$ biomassa serbuk kayu. Equivalence Ratio (ER) dilakukan 4 variasi yaitu: 1,$01 ; 1,13 ; 1,34 ; 1,52$. Data-data yang dicatat berupa: temperatur di dalam reaktor, waktu operasi gasifikasi, debit udara masuk, kandungan syngas, dan visualisasi nyala api. Hasil yang didapatkan dari proses gasifikasi menunjukkan bahwa semakin tinggi Equivalence Ratio (ER) maka heating value syngas mengalami penurunan. LHV pada ER 1,52 sebesar 3980,306 Kj/m ${ }^{3}$ serta kandungan synthetis gas mengalami penurunan sebesar 21,7806 \%
\end{abstract}

Kata Kunci: Gasifikasi biomassa, downdraft, distribusi temperatur, equivalensi ratio, visualisasi nyala syngas

\begin{abstract}
The depletion of fossil fuel reserves and natural gas makes people rethink to find alternative energy substitutes. Biomass is an alternative energy that is still abundant and has not been fully utilized. Gasification is one of alternative in gas making that change from solid fuel (wood powder) to thermochemical flammable gas. The research used downdraft gasification with experimental wood powder. The implementation of research was done in workshop of Indramayu State of Polytechnic, using batch system, it means once the import of biomass in the furnace from the beginning until the biomass out by $5 \mathrm{~kg}$ of wood powder biomass. Equivalence Ratio (ER) performed 4 variations namely: $1.01 ; 1.13 ; 1.34 ; 1.52$. The recorded data are: temperature inside reactor, gasification operation time, air intake, syngas content, and flame visualization. The results obtained from the gasification process showed if the Equivalence Ratio (ER) is higher so the heating value of syngas decrease. LHV at ER 1.52 of 3980,306 Kj / $\mathrm{m}^{3}$ and the synthetis gas content decreased as much as $21,7806 \%$
\end{abstract}

Keywords: Biomass gasification, downdraft, equivalence ratio, syngas flame visualization, temperature distribution.

\section{PENDAHULUAN}

Ketersediaan sumber energi alternatif khususnya biomassa sangat melimpah dan belum dimanfaatkan secara optimal sebagai sumber energi alternatif bahan bakar minyak (BBM). Biomassa bukan hanya sumber energi, tapi juga sumber material, yaitu bahan baku [1] Penggunaan energi alternatif biomassa dari serbuk kayu yang sangat ramah lingkungan akan menjadi pilihan guna memperbarui energi dari fosil yang selama ini cadangan semakin menipis. Pemerintah mencanangkan penggunaan energi alternatif untuk mengurangi beban APBN. Konsumsi minyak global sebesar 1,2 juta barel per hari, cadangan minyak di dunia berkurang dengan sangat cepat. Bahkan, produksi minyak dunia telah mencapai puncaknya pada tahun 2005 dan sejak saat itu tidak ada lagi peningkatan yang melebihi produksi maksimal tersebut. ketergantungan energi fosil masih didominasi oleh kebutuhan minyak yang mencapai 41,8 persen, 
disusul batu bara 29 persen dan gas 23 persen. Kebutuhan ini untuk memenuhi sektor industri yang mendominasi sebesar 37 persen penggunaan energi fosil. Kebutuhan yang sangat besar ini ternyata tidak bisa ditopang oleh cadangan energi di Indonesia yang kian menipis. Cadangan minyak misalnya, hanya cukup untuk 23 tahun lagi. Sementara cadangan gas masih cukup sampai 50 tahun ke depan dan batu bara cukup untuk 80 tahun mendatang $[1,2]$.

Penelitian ini menggunakan gasifikasi tipe downdraft dimana proses konversi biomassa secara thermokimia menjadi gas yang memiliki nilai bakar (flammable gas) dengan cara oksidasi parsial pada temperatur tinggi. Gasifikasi dengan bahan baku biomass padat ini terjadi pada kondisi yang terisolasi dari udara sekitar (oksigen terbatas), ruangan tertutup, dan berada pada tekanan yang relatif terhadap tekanan ambient. Gasgas yang dihasilkan dari proses gasifikasi umumnya berbentuk $\mathrm{CO}, \mathrm{CO}_{2}, \mathrm{H}_{2}$ dan $\mathrm{CH}_{4}$ yang kemudian gas- gas ini disebut Syngas atau Synthetic Gas. Nilai kalori dari gas hasil ini berkisar antara 1000- $1200 \mathrm{kcal} \mathrm{Nm}^{3}$ [3]. Bahan bakar padat yang dimaksud adalah berupa biomass, batubara atau arang.

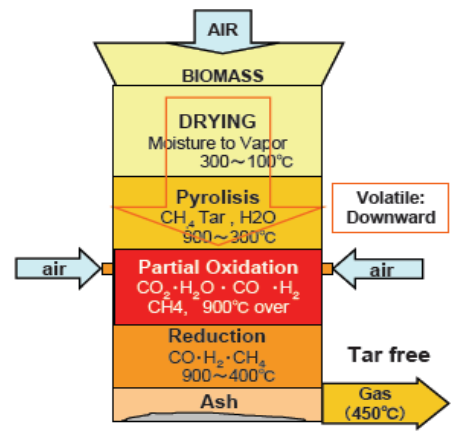

Gambar 1. Gasifier tipe downdraft

Pada gasifier tipe downdraft terdapat empat zona diurut dari bagian atas gasifier hingga bawah yaitu pengeringan, pyrolisis, oksidasi, dan reduksi. Pada tipe ini bahan bakar (biomass) dan udara dimasukkan dari bagian atas gasifier melalui laluan hopper dan mengalir turun ke grate yang merupakan tempat abu. Sementara pada gasifier tipe updraft juga terdapat empat zona dengan urutan dari atas ke bawah yaitu pengeringan, pirolisis, reduksi, dan oksidasi. Gasifier tipe updraft merupakan counterflow reactor dimana bahan bakar dimasukkan dari bagian atas dan selama operasi bahan bakar ini akan mengalir ke bawah, sementara gasifying agent yang berupa udara, uap, atau oksigen dihembuskan dari bawah dan mengalir ke atas $[3,4]$.

Proses konversi biomassa ini dapat dilakukan secara langsung maupun tidak. Konversi secara langsung dapat dilakukan dengan proses pembakaran, sedangkan konversi secara tidak langsung dapat dilakukan dengan proses pirolisis dan gasifikasi. Yang membedakan keduanya dengan proses pembakaran adalah hasil prosesnya dan perbandingan antara jumlah bahan bakar (biomassa) dengan udara yang digunakan (AFR), seperti terlihat pada skema berikut:

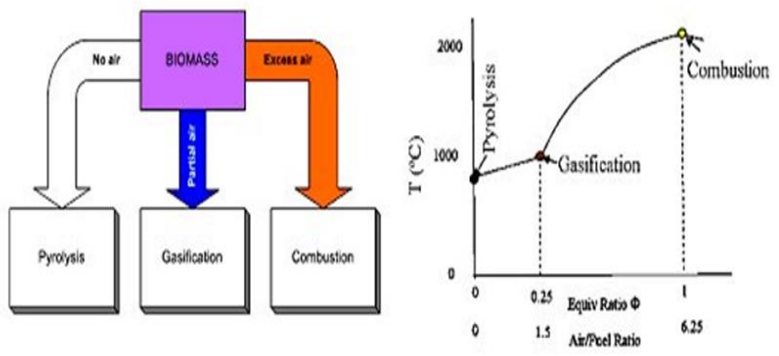

Gambar 2. Perbandingan udara-biomassa

Gasifikasi tipe downdraft [4] memiliki 4 (empat) yaitu dring, pyrolisis, gasifikasi (reduction), oxidasi (pembakaran). Dimana pada tahapan ini memiliki reaksi kimia:

Drying zone

MainFeedstock + Heat $\rightarrow+H 2$

Pyrolisis zone

DryFeedstock + Heat $\rightarrow$ char + Volatiles .......(2.2)

Gasification (reduction)

Boudouard reaction

$\mathrm{C}+\mathrm{O}_{2} \rightarrow 2 \mathrm{CO} \quad(-164.9 \mathrm{MJ} / \mathrm{kgmol})$

Steam-carbon reaction :

$\mathrm{C}+\mathrm{H}_{2} \mathrm{O} \rightarrow \mathrm{CO}+2 \mathrm{H}(-122.6 \mathrm{MJ} / \mathrm{kgmol})$

water-gas shift reaction

$\mathrm{CO}+\mathrm{H}_{2} \mathrm{O}=\mathrm{CO}_{2}+\mathrm{H}_{2}(+42,3 \mathrm{MJ} / \mathrm{kgmol})$

methanation

$\mathrm{C}+2 \mathrm{H}_{2} \rightarrow \mathrm{CH}_{4}(+75 \mathrm{MJ} / \mathrm{kgmol})$

$\mathrm{CO}+3 \mathrm{H}_{2} \rightarrow{ }_{4}+\mathrm{H}_{2} \mathrm{O}(-205.9 \mathrm{MJ} / \mathrm{kgmol})$

Oksidasi (combustion)

$\mathrm{C}+\mathrm{O}_{2} \rightarrow \mathrm{CO}_{2}(+393 \mathrm{MJ} / \mathrm{kgmole})$.

$2 \mathrm{H}_{2}+\mathrm{O}_{2} \rightarrow 2 \mathrm{H}_{2} \mathrm{O}(+242 \mathrm{MJ} / \mathrm{kgmole})$.

Penelitian terdahulu tentang equivalensi ratio gasifikasi downdraft sudah dilakukan oleh Feiqiang Guo dkk [4] melakukan penelitian gasifikasi dengan bahan bakar tongkol jagung (corn stalk) dengan equivalensi ratio 0,18-0,37 pada gasifier tipe downdraft, dari penelitian tersebut menunjukkan bahwa pada ER 0.25-0.27, dihasilkan gas produk dalam kondisi terbaik dimana memiliki LHV sekitar $5400 \mathrm{~kJ} / \mathrm{m}^{3}$ dan cold gas efficiency $65 \%$. Meningkatnya LHV dikarenakan meningkatnya kandungan $\mathrm{H} 2$ dan CO. Sudarmanta dkk [4], melakukan penelitian gasifikasi downdraft dengan bahan bakar sekan padi dengan dua tingkat laluan udara. Hasil karakterisasi suhu proses gasifikasi menggunakan reaktor downdraft dengan pendekatan sistem batch ini adalah sebagai berikut:

- Drying pada suhu $100 \sim 150{ }^{\circ} \mathrm{C}$

- Pirolisis sampai suhu $300{ }^{\circ} \mathrm{C}$

- Oksidasi parsial sampai suhu $960{ }^{\circ} \mathrm{C}$

- Reduksi pada suhu $400-500{ }^{\circ} \mathrm{C}$

Identifikasi losses berdasarkan kesetimbangan energi menunjukkan masih adanya losses hingga $20 \%$ diluar losses arang karbon, ash dan losses panas ke lingkungan Efisiensi thermal dari reactor gasifikasi mencapai $50 \%$ pada kondisi pemanasan udara pada suhu $50{ }^{\circ} \mathrm{C}$.

Aydar, Emir dkk [5] melakukan penelitian Pada proses gasifikasi batu bara dapat menggunakan gasifying 
agent tunggal maupun campuran, yang paling sering digunakan adalah udara, oksigen, karbon dioksida, dan uap. Penggunaan udara sebagai gasifying agent banyak digunakan karena cukup dengan suplay udara dari blower sehingga lebih murah daripada gasifying agent lainnya. Gasifying agent berdampak pada kualitas dan kuantitas syngas. Ada empat agen gasifikasi umum digunakan : udara, uap, oxygen dan campuran udara-uap. Penggunaan gasifying agent dapat mempengaruhi komposisi gas, kandungan tar, dan heating value.

Tabel 1. karakteristik syngas berdasarkan gasifying agent

\begin{tabular}{|c|c|c|c|c|c|c|}
\hline \multirow{2}{*}{$\begin{array}{c}\text { Gasification } \\
\text { Agent }\end{array}$} & \multirow{2}{*}{$T\left({ }^{0} \mathrm{C}\right)$} & \multicolumn{2}{|c|}{ Gas Composition (dry basis) } & \multicolumn{3}{|c|}{ Yields } \\
\hline & & $H_{2}(\%)$ & $\mathrm{CO}(\%)$ & $\operatorname{Tar}(\mathrm{gkg})$ & Gas $(\mathrm{Nm} / \mathrm{kg})$ & LHV $\left(\mathrm{MJ} / \mathrm{Nm}^{3}\right)$ \\
\hline Air & 780.830 & $5.0-16.3$ & $9.9 \cdot 22.4$ & 3.7 .61 .9 & $1.25 \cdot 2.45$ & 3.7 .8 .4 \\
\hline 02-Steam & $785-830$ & 13.8 .31 .7 & 42.5 .52 .0 & 2.246 & $0.86 \cdot 1.14$ & $10.3 \cdot 13.5$ \\
\hline Steam & 750.780 & 38.56 & 17.32 & 60.95 & $1.3 \cdot 1.6$ & $12.2 \cdot 13.8$ \\
\hline
\end{tabular}

Komposisi gas tergantung pada bahan bakar, gasifying agent, jenis gasifier, ER , dan jenis katalis. Pada proses gasifikasi dengan menggunakan udara sebagai gasifying agent, syngas mengandung flammable gas dan non flammable gas. Flammable gas terdiri dari gas $\mathrm{CO}, \mathrm{CH}_{4}$, $\mathrm{H}_{2}$, sedangkan non-flamable gas terdiri dari gas $\mathrm{N}_{2}$ dan $\mathrm{CO}_{2}$.

Waldheim, L [6] meneliti untuk nilai kalor bawah atau low heating value pada gas yang diproduksi dari kosentrasi gas yang terbakar $\left(\mathrm{CO}, \mathrm{CH}_{4}, \mathrm{H}_{2}\right)$ yaitu

$L H V_{G A S}=\sum_{i=1}^{n}\left(Y_{i} \cdot L H V_{i}\right)$

Keterangan :

$Y_{i} \quad=$ Prosentase flammable gas $\left(\mathrm{CO}, \mathrm{CH}_{4}, \mathrm{H}_{2}\right)$

$\mathrm{LHV}_{i}=$ Nilai kalor bawah gas terbakar $\left(\mathrm{CO}, \mathrm{CH}_{4}, \mathrm{H}_{2}\right)$

Tabel 2. $\mathrm{LHV}_{\mathrm{i}}$ dari flammable gas $\left(\mathrm{CO}, \mathrm{CH}_{4}, \mathrm{H}_{2}\right)$

\begin{tabular}{|c|c|}
\hline Gas yang terbakar & $\boldsymbol{H H V}_{\boldsymbol{i}}\left(\frac{\boldsymbol{k J}}{\boldsymbol{m}^{\mathbf{3}}}\right)$ \\
\hline $\mathrm{CO}$ & 12630 \\
\hline $\boldsymbol{C H}_{\mathbf{4}}$ & 39820 \\
\hline $\boldsymbol{H}_{\mathbf{2}}$ & 12740 \\
\hline
\end{tabular}

\section{METODE}

Pengujian dilakukan dengan metode eksperimental untuk mengetahui rasio bahan bakar dan udara yang tepat sehingga didapatkan gas hasil gasifikasi yang flammable. Gasifikasi dengan type bed yaitu pemasukan biomassa dilakukan dengan satu kali kemudian pengambilan data dilakukan sehingga seluruh biomassa habis terbakar dan syngas tidak diproduksi lagi. Penelitian tersebut dilakukan pada reaktor gasifikasi dengan metode downdraft di kampus Jurusan Teknik Mesin Politeknik Negeri Indramayu.

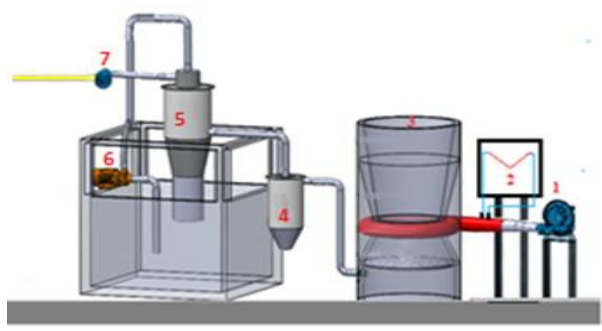

Gambar 3. Skema Sistem Pengujian

Keterangan

1. Blower tekan

2. Manometer U

3. Reaktor Gasifikasi

4. Cyclone

5. Water scrubber

6. Pompa air

7. Pompa hisap

Prosedur pengujian dengan memasukkan bahan bakar biomassa kedalam tungku dengan rata, selanjutnya serbuk kayu dalam reaktor dinyalakan dan induced fan dihidupkan untuk melakukan pemanasan awal tungku reaktor. Setelah beberapa menit, dimulailah proses pengambilan data sistem batch dan suhu yang ada didalam reaktor mencapai $500^{\circ} \mathrm{C}$ keatas. Setelah itu pengukuran pada reaktor dimulai pada 5 posisi thermokople dengan interval 10 menit.

\section{HASIL DAN PEMBAHASAN}

Equivalence ratio (ER) adalah salah satu parameter penting dalam proses gasifikasi sehingga ER berdampak pada kualitas dan kuantitas syngas yang diproduksi. Dampak dari ER seperti komposisi syngas, heating value, dan kandungan tar [7,8]. ER dalam proses gasifikasi menggunakan udara dengan jumlah yang terbatas. ER yang terlalu tinggi maupun terlalu rendah menimbulkan beberapa permasalahan. Jika ER terlalu kecil maka produk char bertambah, produksi syngas yang kecil, serta heating value yang rendah. Sebaliknya pada ER yang tinggi dimana penggunaan jumlah udara yang besar maka meningkatkan komposisi gas $\mathrm{CO}_{2}$ dan $\mathrm{H}_{2} \mathrm{O}$ dikarenakan semakin mendekati pembakaran sempurna [8]. Kehadiran gas $\mathrm{CO}_{2}$ dan $\mathrm{H}_{2} \mathrm{O}$ mengakibatkan prosentase flammable gas $\mathrm{CO}$ dan $\mathrm{H}_{2}$ turun sehingga heating value nya turun pula. ER pada proses gasifikasi biasanya berkisar antara 0.2-0.3. Semakin tinggi nilai ER maka jumlah udara yang dimasukkan ke dalam gasifier semakin besar. Equivalence ratio dihitung berdasarkan jumlah aktual udara/bahan bakar yang dimasukkan ke gasifier dibagi jumlah udara/bahan bakar stokiometri. Pada penelitian ini variasi ER dilakukan dengan memvariasikan putaran blower menggunakan dimmer sehingga m udara yang memasuki gasifier akan berbeda.Rumus ER yaitu [9].

$$
\mathrm{ER}=\frac{\left(\dot{m}_{\text {air }} / \dot{m}_{\text {fuel }}(\text { ar })\right) \text { aktual }}{\left(\dot{m}_{\text {air }} / \dot{m}_{\text {fuel }}(\text { ar })\right) \text { Stoich }}=\frac{\mathrm{AFR}_{\text {Aktual }}}{\mathrm{AFR}_{\text {Stoic }}}
$$


Keterangan ER = Equivalence Ratio

$\left(\dot{m}_{\text {air }} / \dot{m}_{\text {fuel }}(\right.$ ar $\left.)\right)$ aktual $=$ mass flow udara bandingkan mass flow bahan bakar pada kondisi aktual

$\left(\dot{m}_{\text {air }} / \dot{m}_{\text {fuel }}(\right.$ ar $\left.)\right)$ Stoich $=$ mass flow udara dibandingkan mass flow bahan bakar pada kondisi pembakaran sempurna (stoichiometry)

$\frac{\dot{m}_{\text {air }}}{\dot{m}_{\text {fuel }}}$ stoich adalah perbandingan jumlah udara dan bahan bakar yang dibutuhkan untuk mendapatkan pembakaran yang sempurna atau biasa disebut $\mathrm{AFR}_{\text {stoich }}[10]$. Perhitungan $\frac{\dot{m}_{\text {air }}}{\dot{m}_{\text {fuel }}}$ stoich serbuk kayu diambil dari uji ultimate biomassa pada kondisi ar (as received). Rumus kimia untuk kesetimbangan stoikiometri nya adalah :

$$
\begin{aligned}
& \mathrm{C}_{\alpha} \mathrm{H}_{\beta} \mathrm{O}_{\gamma}+\left(\alpha+\frac{\beta}{4}-\frac{\gamma}{2}\right)\left(\mathrm{O}_{2}+3.76 \mathrm{~N}_{2}\right) \text { atau } \\
& \alpha \mathrm{CO}_{2}+\frac{\beta}{2} \mathrm{H}_{2} \mathrm{O}+3.76\left(\alpha+\frac{\beta}{4}-\frac{\gamma}{2}\right) \mathrm{N}_{2} \\
& \frac{\dot{m}_{\text {air }}}{\dot{m}_{\text {fuel }}} \text { stoich }=4,76\left(\alpha+\frac{\beta}{4}+\frac{\gamma}{2}\right) \frac{M W \text { air }}{M W \text { fuel }} \\
& \mathrm{A} / \mathrm{F}_{\text {stoic }} \quad=\text { air }- \text { fuel ratio } \text { stoikiometri } \\
& \text { MW air = Molecular weight air }(28,85) \\
& \text { MW fuel = Molecular weight fuel }(98,38)
\end{aligned}
$$

\section{Analisis Distribusi Temperatur}

Dalam proses gasifikasi terdapat lima tahapan proses dalam menghasilkan syngas, yaitu tahap drying, pirolisis, oksidasi parsial dan reduksi. Masing-masing tahapan tersebut memiliki interval temperatur yang berbeda sebagai indikatornya. Dari beberapa tahapan yang sesuai dengan variasi maka equivalensi ratio [11] .

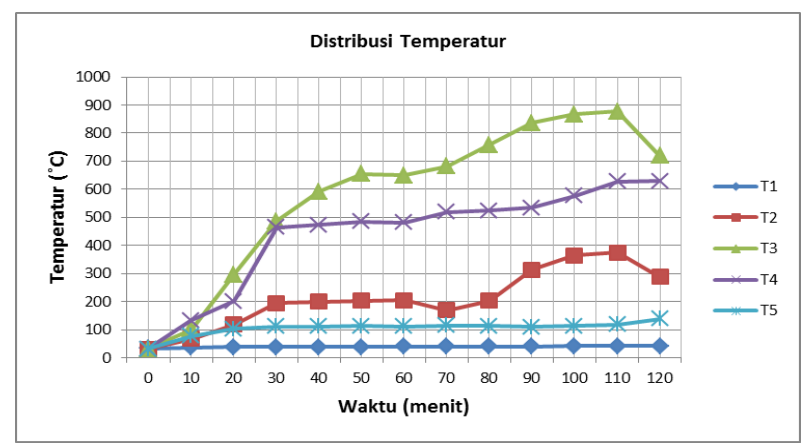

Gambar 4. Distribusi Temperatur $=\mathrm{f}($ waktu $)$ pada pada ER 1,01

Pada Gambar 4 di atas, termokopel $1\left(\mathrm{~T}_{1}\right)$ memiliki temperatur konstan sampai $43^{\circ} \mathrm{C}$, mengindikasikan bahwa termokopel 1 masih merupakan permulaan zona drying, dimana kandungan moisture yang dimiliki serbuk kayu dihilangkan melalui proses penguapan atau evaporasi. Untuk termokopel $2\left(\mathrm{~T}_{2}\right)$ memiliki temperatur kisaran sampai $271^{\circ} \mathrm{C}$ mengindikasikan bahwa, $\mathrm{T}_{2}$ ini akan masuk zona pirolysis, dengan temperatur $300^{\circ} \mathrm{C}-900^{\circ} \mathrm{C}$, dimana biomassa kering yang bebas dari moisture, mengalami pemanasan terus-menerus yang diharapkan mampu menghilangkan kandungan volatile. Biomassa yang mengalami pemanasan pada temperatur tinggi akan menyebabkan biomassa terpecah menjadi arang (C), tar, minyak, gas dan produk pirolisa lain. Produk pirolisis umumnya terdiri dari tiga jenis, yaitu gas ringan $\left(\mathrm{H}_{2}, \mathrm{CO}\right.$, $\mathrm{CO}_{2}, \mathrm{H}_{2} \mathrm{O}$, dan $\mathrm{CH}_{4}$ ), tar, dan arang. Secara umum reaksi yang terjadi pada pirolysis beserta produknya adalah:

\section{Biomassa $\rightarrow$ char+tar + gases $\left(\mathrm{CO}_{2} ; \mathrm{CO} ; \mathrm{H}_{2} \mathrm{O} ; \mathrm{H}_{2} ; \mathrm{CH}_{4}\right.$; $\mathrm{CnHm})$}

Sedangkan termokopel $3\left(\mathrm{~T}_{3}\right)$ memiliki temperatur paling tinggi dengan kisaran sampai $706^{\circ} \mathrm{C}$, mengindikasikan bahwa $\mathrm{T}_{3}$ akan masuk zona oksidasi parsial sesuai dengan, zona oksidasi parsial akan memasuki temperatur $>900^{\circ} \mathrm{C}$, dimana proses ini menghasilkan panas (reaksi eksoterm) yang memanaskan lapisan karbon dibawah. Proses ini dipengaruhi distribusi oksigen karena adanya oksigen inilah, terjadi reaksi eksoterm yang menghasilkan panas, yang dibutuhkan dalam keseluruhan proses gasifikasi ini. Sekitar $20 \%$ arang bersama volatile akan mengalami oksidasi menjadi $\mathrm{CO}_{2}$ dan $\mathrm{H}_{2} \mathrm{O}$ dengan memanfaatkan oksigen terbatas yang disuplaikan ke dalam reaktor (hanya 20\% dari keseluruhan udara yang digunakan dalam pembakaran dalam reaktor). Reaksi kimia yang terjadi pada zona ini adalah sebagai berikut :

$$
\begin{gathered}
\mathrm{C}+\mathrm{O}_{2} \rightarrow \mathrm{I} / 4 \mathrm{CO}_{2}+408 \mathrm{~kJ} / \mathrm{mol} \\
2 \mathrm{C}+\mathrm{O}_{2} \rightarrow 1 / 42 \mathrm{CO}+246 \mathrm{~kJ} / \mathrm{mol} \\
\mathrm{H}_{2}+\mathrm{I} / 2 \mathrm{O}_{2} \rightarrow \mathrm{H}_{2} \mathrm{O}+242 \mathrm{MJ} / \mathrm{kmol}
\end{gathered}
$$

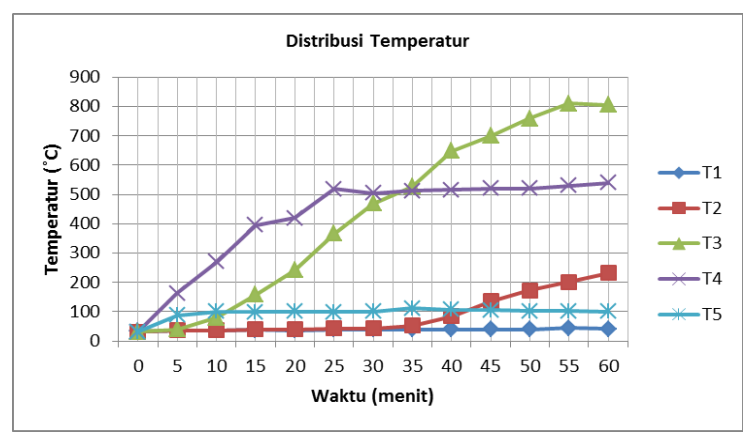

Gambar 5. Distribusi Temperatur $=\mathrm{f}($ waktu $)$ pada ER 1,13

Pada gambar 5 di atas yaitu termokopel $1\left(\mathrm{~T}_{1}\right)$ memiliki rentang temperatur yang sama dengan variasi (Air Fuel Ratio) sebelumnya yakni ER 1,01 sampai $40^{\circ} \mathrm{C}$, mengindikasikan bahwa termokopel 1 merupakan permulaan zona drying, dimana kandungan moisture yang dimiliki serbuk kayu dihilangkan melalui proses penguapan atau evaporasi. Untuk termokopel $2\left(\mathrm{~T}_{2}\right)$ memiliki rentang temperatur yang sama dengan variasi ER sebelumnya yakni ER 1,01 sampai dengan temperatur $232^{\circ} \mathrm{C}$ mengindikasikan bahwa, $\mathrm{T}_{2}$ ini akan masuk zona pirolysis sesuai dengan dasar teori pada bab 2 bahwa, zona pirolysis memasuki temperatur $300^{\circ} \mathrm{C}-900^{\circ} \mathrm{C}$, dimana biomassa yang mengalami pemanasan terus- 
menerus, diharapkan mampu menghilangkan kandungan volatile biomassa.

Sedangkan pada termokopel $3\left(\mathrm{~T}_{3}\right)$, fenomena distribusi temperatur yang terjadi memiliki rentang temperatur yang sama dengan variasi ER sebelumnya, hanya saja terdapat pada termokopel $3\left(\mathrm{~T}_{3}\right)$ temperatur yang terjadi lebih tinggi yaitu $1000^{\circ} \mathrm{C}$ daripada $\mathrm{T}_{3}$ pada ER 1,01 ini dikarenakan, semakin tinggi ER maka semakin cepat pula daya hisap blower sehingga proses terjadinya pembakaran di dalam reaktor lebih cepat.

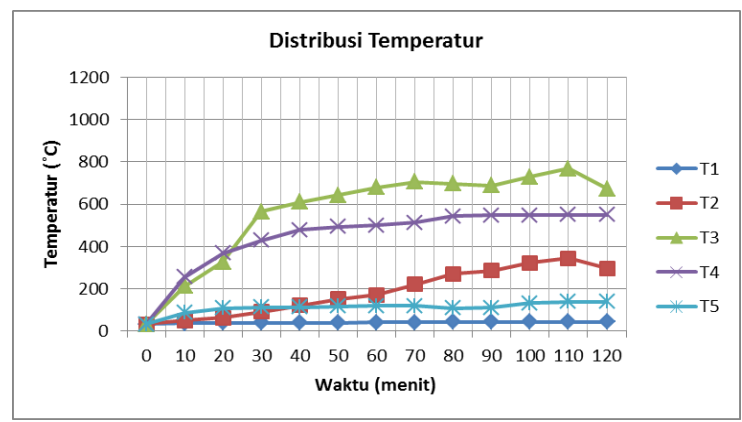

Gambar 6. Distribusi Temperatur $=\mathrm{f}($ waktu $)$ pada ER 1,34

Pada gambar 6 di atas yaitu termokopel $1\left(\mathrm{~T}_{1}\right)$ memiliki rentang temperatur yang sama dengan variasi sebelumnya yakni ER 1,13 sampai $40^{\circ} \mathrm{C}$, mengindikasikan bahwa termokopel 1 merupakan permulaan zona drying, dimana kandungan moisture yang dimiliki serpihan kayu dihilangkan melalui proses penguapan atau evaporasi. Untuk termokopel $2\left(\mathrm{~T}_{2}\right)$ memiliki rentang temperatur yang sama dengan variasi ER sebelumnya yakni ER 1,13 sampai dengan temperatur $232^{\circ} \mathrm{C}$ mengindikasikan bahwa, $\mathrm{T}_{2}$ ini akan masuk zona pirolysis sesuai dengan dasar teori sebelumnya bahwa, zona pirolysis memasuki temperatur $300^{\circ} \mathrm{C}-900^{\circ} \mathrm{C}$, dimana biomassa yang mengalami pemanasan terusmenerus, diharapkan mampu menghilangkan kandungan volatile biomassa. Sedangkan pada termokopel $3\left(\mathrm{~T}_{3}\right)$, fenomena distribusi temperatur yang terjadi memiliki rentang temperatur yang sama dengan variasi ER sebelumnya, hanya saja terdapat pada termokopel $3\left(\mathrm{~T}_{3}\right)$ temperatur yang terjadi lebih tinggi yaitu $1000^{\circ} \mathrm{C}$ daripada $\mathrm{T}_{3}$ pada ER 1,13 ini dikarenakan, semakin tinggi ER maka semakin cepat pula daya hisap blower sehingga proses terjadinya pembakaran di dalam reaktor lebih cepat.

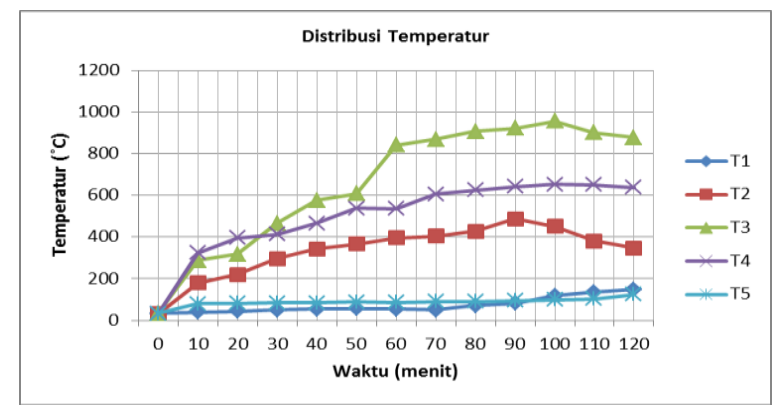

Gambar 7. Distribusi Temperatur = f (waktu) pada ER 1,52
Pada gambar 7 diatas yaitu termokopel $1 \quad\left(\mathrm{~T}_{1}\right)$ memiliki rentang temperatur yang sama dengan variasi ER sebelumnya yakni ER 1,01; 1,13 sampai dengan temperatur $37^{\circ} \mathrm{C}$, mengindikasikan bahwa termokopel 1 merupakan permulaan zona drying, dimana kandungan moisture yang dimiliki serpihan kayu dihilangkan melalui proses penguapan atau evaporasi. Untuk termokopel 2 $\left(\mathrm{T}_{2}\right)$ memiliki rentang temperatur yang sama dengan variasi ER sebelumnya sampai dengan temperatur $275^{\circ} \mathrm{C}$ mengindikasikan bahwa, $\mathrm{T}_{2}$ ini akan masuk zona pirolisis sesuai dengan ER 1,34, zona pirolisis memasuki temperatur $300^{\circ} \mathrm{C}-900^{\circ} \mathrm{C}$, dimana biomassa yang mengalami pemanasan terus-menerus, diharapkan mampu menghilangkan kandungan volatile biomassa.

\section{KOMPOSISI SYNGAS}

Dari hasil equivalensi ratio antara serbuk kayu dan udara didapatkan hasil akhir yaitu flamable gas. Komposisi syngas yang dihasilkan merupakan hasil perbandingan antara serbuk kayu yang ada didalam reaktor dengan perbandingan udara yang masuk.[12] pada setiap ER menunjukkan warna yang berbeda, ini dikarenakan perbandingan antara bahan bakar tetap dan tekan udara berbeda. Karena sesuai dengan perhitungan yang dilakukan maka total gas yang terbakar cenderung mengalami penurun pada ER. Berikut visualisasi gas pada equivalensi ratio pada setiap tingkatan:

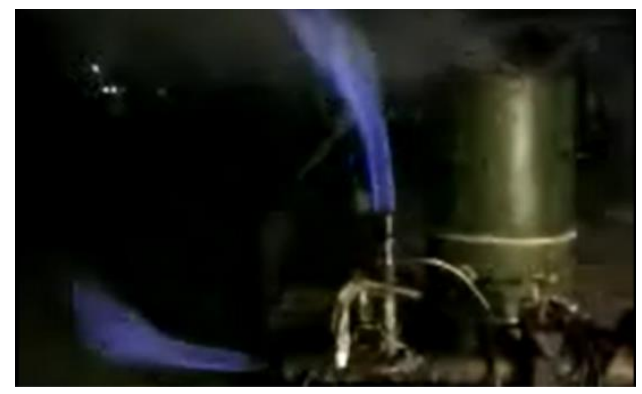

Gambar 8. Visualisasi Warna Api ER 1,01

Warna pada komposisi syngas ER 1,01 didominasi warna merah kebiruan. Dari prosentase kandungan syntetis gas pada ER 1,01 memiliki 25,269\% gas yang mudah terbakar dari total $95 \%$. Dari hasil perhitungan konsentrasi kandungan synthetis gas pada ER ini nilai $\mathrm{CH}_{4}$ sebesar 1,0417\%, $\mathrm{H}_{2}$ sebesar 5, $59789 \%, \mathrm{~N}_{2}$ sebesar $49,98523 \%, \mathrm{CO}$ sebesar $18,99 \%, \mathrm{CO}_{2}$ sebesar $11,73917 \%, \mathrm{O}_{2}$ sebesar 7,64601\%. Dari perhitungan pada masing masing kandungan syngas nilai $\mathrm{CH}_{4}$ pada equivalensi ratio 1,01 merupakan Kandungan yang tertinggi dari empat variasi yang dilakukan. Visualisasi warna api pada tingkatan ini merupakan campuran yang terbaik antara udara yang masuk dengan serbuk kayu yang ada didalam reaktor gasifikasi. 


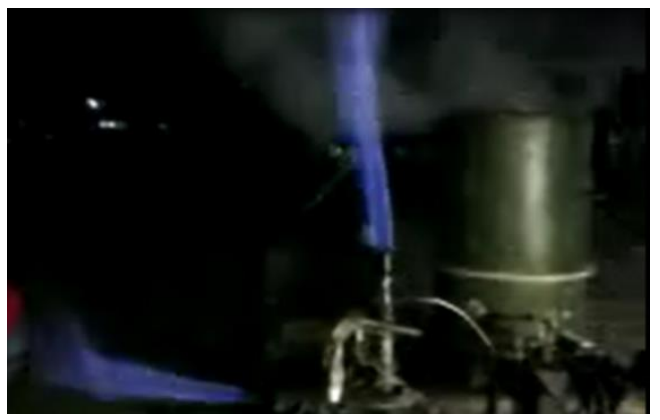

Gambar 9. Visualisai Warna Api ER 1,13

Perbadaan visualisasi warna api pada ER 1,01 dan 1,13 tidak ada perbedaan. Warna api hampir sama tetapi hasil perhitungan dari bentuk warna api pada ER 1,13 berbeda, dari perhitungan nilai kandungan syntetis gas yang dihasilkan dari ER 1,13 cenderung mengalami penurunan yaitu $\mathrm{CH}_{4}$ sebesar $1,42277 \%, \mathrm{H}_{2}$ sebesar $5,19365 \%, \mathrm{~N}_{2}$ sebesar $41,19869 \%$, CO sebesar $17,93 \%$, $\mathrm{CO}_{2}$ sebesar $11,87131 \%, \mathrm{O}_{2}$ sebesar $16,38359 \%$

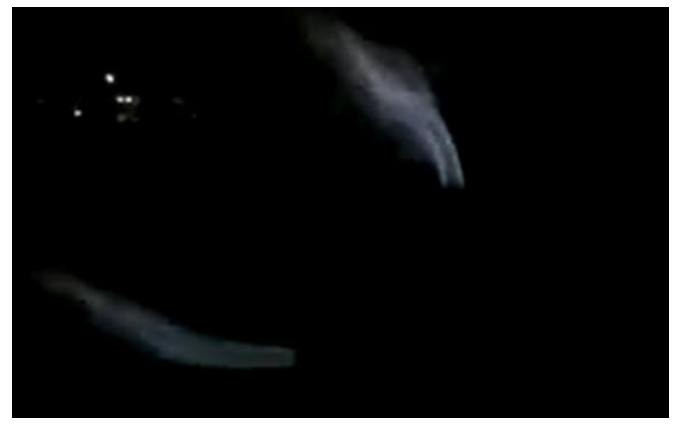

Gambar 10. Visualisai Warna Api ER 1,34

Perbadaan visualisasi warna api pada ER 1,34 mulai terlihat perbedaaan. Warna api cenderung kuning kemerahan ini dikarenakan komposisi dari syngas tersebut mengalami penurunan. Kandungan dari komposisi syngas pada ER 1,34 untuk $\mathrm{CH}_{4}$ sebesar $1,9805 \%, \mathrm{H}_{2}$ sebesar $4,79341 \%, \mathrm{~N}_{2}$ sebesar $43,72858 \%$, CO sebesar $17,01 \%, \mathrm{CO}_{2}$ sebesar $11,26141 \%, \mathrm{O}_{2}$ sebesar $16,22607 \%$

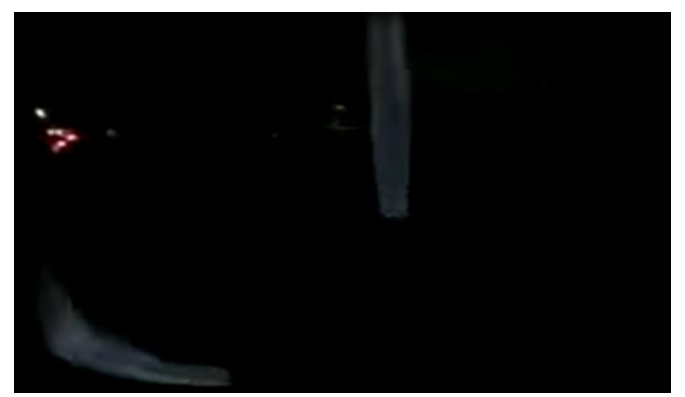

Gambar 11. Visualisai Warna Api ER 1,52

Warna api pada ER 1,52 warna cenderung didominasi Kuning. Hal ini menunjukkan bahwa biomassa yang terbakar sudah hampir habis sedangkan udara konstan. Sehingga gas yang keluar lebih banyak campuran udara. dari perhitungan nilai kandungan syntetis gas yang dihasilkan dari ER 1,52 cenderung mengalami penurunan yaitu $\mathrm{CH}_{4}$ sebesar $1,8155 \%, \mathrm{H}_{2}$ sebesar 5,3951\%, $\mathrm{N}_{2}$ sebesar 49,2679\%, CO sebesar $14,57 \%, \mathrm{CO}_{2}$ sebesar $11,234 \%, \mathrm{O}_{2}$ sebesar $12,79654 \%$

\section{PENUTUP}

\section{Kesimpulan}

a. Semakin tinggi ER maka gas yang dihasilkan semakin rendah karena gas yang terbentuk sedikit.

b. Apabila ER tinggi harus disertai bahan bakar yang besar pula untuk mengimbangi besarnya udara yang masuk sehingga gas yang terbentuk akan lebih baik.

c. Komposisi syngas biomassa cenderung lebih kecil apabila dibandingkan dengan batubara, atau gas yang lain.

d. Komposisi syngas tertinggi berada pada ER 1,01 dan terendah pada ER 1,52

e. LHV tertinggi terjadi pada ER 1,01 sebesar $4530,879883 \mathrm{KJ} / \mathrm{m}^{3}$ dan terendah berada pada ER 1,52 sebesar 3980,306806 KJ/m 3

f. Perlu adanya alat digital yang berfungsi untuk pembacaan terbentuknya gas pada reaktor.

\section{Saran}

Berdasarkan penelitian yang telah dilakukan, penulis menyarankan beberapa hal yang mungkin bisa menjadi masukan untuk pengembangan penelitian gasifikasi lebih lanjut sebagai berikut:

a. Perlu dilakukan penelitian lebih lanjut pada temperatur pada reaktor gasifikasi yang masih mengalami beberapa kendala tentang pembacaan pengukuran (manual) akan lebih baik jika dilakukan secara otomatis.

b. Perancangan reaktor gasifikasi perlu dilakukan secara mendetail guna menghindari kerugian-kerugian akibat kebocoran gas.

c. Pembacaan flowmeter gas perlu ditingkatkan sehingga didapat hasil yang akurat.

d. Perlu disesuaikan kembali Blower hisap dengan perhitungan pada reaktor agar didapat hasil gas yang maksimal.

\section{DAFTAR PUSTAKA}

[1] https://m.tempo.co/red/news/2015/12/23/09273012.

[2] Lydia Stougie, Georgios A. Tsalidis, Hedzer J. van der Koo, Gijsbert Korevaar. (2017) "Environmental and exergetic sustainability assessment of power generation from biomass." Renewable Energy xxx $1-9$

[3] Bhavanam,A. dan Sastry,R.C. (2011), "Biomass Gasification Processes in Downdraft Fixed Bed Reactors: A Review", International Journal of Chemical Engineering and Applications, Vol. 2, No. 6.

[4] Guo Feiqiang, Dong Yuping, dan Dong Lei. (2014), "Effect of design and operating parameters on the gasification process of biomass in a downdraft fixed bed: An experimental study', 
Sciencedirect,International Journal Of Hydrogen Energy ,No.39, hal. 5625-5633.

[5] Aydar, Emir dkk. (2014). " Effect Of The Type Of Gasifying agent On Gas Composition In A Bubbling Fluidized Bed reaktor". Jurnal Of The Energy Institute. Volume 87, Issue 1, Page 35-42.

[6] Waldheim, L. and Nilson, T., (2011),"Heating value of gases from biomass gasification", Report Prepared for IEABioenergy Agreement, Biomass \& Bio Energy, Task 20 Thermal Gasification of Biomass.

[7] Trifiananto, M. (2014)," Karakterisasi Gasifikasi Batubara type Updraft Dengan Variasi Equivalensi ratio",Seminar Nasional Teknik Mesin 9, Surabaya.

[8] Ye Mint Htut. (2015), " Experimental Investigation of the Pilot Scale Downdraft Gasifier". Int'l Journal of Research of Chemical, Metallurgical and Civil Engg. (IJRCMCE) Vol.2, Issue 1 ISSN 2349-1442 EISSN 2349-1450

[9]. Adrieq, A dan Sudarmanta, B. (2016). “ Studi Eksperimental Pengaruh Air Fuel Ratio Proses Gasifikasi Briket Municipa Solid Waste Terhadap Unjuk Kerja Gasifier Tipe Downdraft”. JURNAL TEKNIK ITS Vol. 1, No. 1, ISSN:

[10] Manish Kumar, Bireswal paul and Dhananjay singh Yadav. (2016), "Effect of Moisture Content and Equivalence Ratio On The gasification Proces For Different Biomass Fuel" International Journal of Mechanical Engineering and Technology (IJMET) Volume 7, Issue 6.

[11] Tamer M. Ismail and M. Abd El-Salam. (2017), "parametric studies on biomass gasification process on updraft gasifier high temperature on gasification" Vollume 112, pages 1460-1473.

[12] P. Punnarapong, T. Sucharitakul, N. Tippayawong. (2017), "Performance evaluation of premixed burner fueled with biomass derived producer gas". Case Studies in Thermal Engineering 9. 